\title{
A HISTÓRIA DA PESTE NA EUROPA SOB A ÓPTICA DA PANDEMIA DE COVID-19 ${ }^{1}$
}

\section{The history of the plague in Europe in the light of the Covid- 19 pandemic}

\author{
Jean-Claude Schmitt ${ }^{2}$ \\ EHESS, Paris \\ Directeur d'étude, EHESS \\ École des Hautes Études en Sciences Sociales, Paris \\ ORCID: https://orcid.org/0000-0001-6237-8293 \\ E-mail: jcsvialas@gmail.com
}

Recebido em: 09/09/2020

Aprovado em: 10/10/2020

\begin{abstract}
Resumé: La pandémie de Covid 19 à partir de janvier 2020 - depuis la Chine vers le reste de l'Asie, puis l'Europe et l'Afrique, et enfin les deux Amériques -, n'est pas sans rappeler des épidémies du passé, souvent bien plus meurtrières encore, en premier lieu celles de la peste (qui emporta le tiers de la population européenne en 1348). Trois épidémies de peste ont frappé l'Europe à travers l'histoire : la Peste de Justinien (541-770), la Peste Noire (1348-1352, suivie de nombreuses récidives jusqu'en 1720) et la peste de Chine (qui n'a touché en fait que les ports européens et américains, entre 1850 et 1940). La peste, par ses agressions ou ses retraits, a une valeur systémique pour le « long Moyen Âge» qui commence dans l'Antiquité tardive et se poursuit jusqu'au XVIIIe siècle : par ses assauts répétés tout au long de cette période, mais aussi par ses retraits comme entre l'époque de Charlemagne et le XIVe siècle ; cet âge « sans peste » correspond à la phase du plus grand essor des campagnes médiévales. Au contraire, quand la peste est de retour entre le XIVe et le XVIIe siècle, elle est un des facteurs décisifs d'une longue stagnation démographique. Jamais la cause véritable de la peste (qu'on attribuait à la corruption de l'air ou à un châtiment de Dieu) n'a été reconnue tout au long de ces siècles. Pourtant on observe dès la fin du Moyen Âge une progression des conceptions « contagionistes » et non-officielles qui anticipent sur la découverte du bacille de la peste par Alexandre Yersin en 1894, en même temps que du rôle des puces et des rats. La peste a suscité des comportements de toutes natures, qui évoquent parfois les mesures prises aujourd'hui pour freiner ou empêcher la progression de l'épidémie (par exemple la quarantaine). Elle a nourri de nouveaux élans de piété et aussi la recherche de boucs-émissaires dont les communautés juives furent les premières victimes. Sur le plan culturel, elle suscita de brillants témoignages littéraires (tel le Decameron de Giovanni Boccacio), mais on ne peut pas lui attribuer la naissance de l'art macabre, car celui-ci lui est antérieur.
\end{abstract}

Mots-clés: Peste, Europe Macabre, Antijudaisme, Contagion Démographie, Zoonose

Abstract: The Covid 19 pandemic from January 2020 - from China to the rest of Asia, then Europe and Africa, and finally the two Americas -, is reminiscent of epidemics of the past, often much more deadly still, in the first place those of the plague (which carried away a third of the European population in 1348). Three plague epidemics have struck Europe throughout history: the Plague of Justinian (541-770), the Black Death (1348-1352, followed by numerous recurrences until 1720) and the Plague of China (which outside Asia only affected European and American ports between 1850 and 1940). The plague, by its aggressions or its withdrawals, has a systemic value for the "long Middle Ages" (which begins in late Antiquity and continues until the 18th century), as well by its repeated assaults throughout this period, as by its withdrawal between the time of Charlemagne and the fourteenth century; this "plague-free" age corresponds to the phase of the greatest growth of the medieval times. On the contrary, when the plague returned between the 14th and 17th centuries, it was one of the decisive factors (beside permanent wars) in a long demographic stagnation. The true cause of the plague (which was officially attributed to the corruption of the air or to a punishment from God) has never been recognized throughout these centuries. However, from the end of the Middle Ages we can observe a progression of "contagionist" and unofficial conceptions which anticipate the discovery of the plague bacillus by Alexandre Yersin in 1894, together with the role of fleas and rats. The plague has given rise to behavior of all kinds, which sometimes evokes the measures taken today to slow down or prevent the progression of the epidemic (for instance the quarantine). It fed new impulses of piety and also the search for scapegoats, of which the Jewish communities were the first victims. Culturally, it aroused brilliant literary testimonies (such as Giovanni Boccacio's Decameron), but we cannot attribute to it the birth of macabre art, because it predates it.

Keywords: Plague, Europe Macabre, Antijudaism, Contagion Demography Zoonosis. 
O ano de 2020 deu ao mundo inteiro a oportunidade, a partir do mês de janeiro, de experienciar, de forma inesperada e, em certos aspectos, sem precedentes, uma pandemia viral que atingiu sucessivamente em tempo recorde a Ásia (a China, berço da epidemia; em seguida a Índia, de maneira ainda mais forte), a Europa (o sul mais que o norte), a África (de forma menos intensa) e sobretudo as duas Américas, do Norte e do Sul, onde não cessa de causar horríveis devastações no momento em que escrevo ${ }^{3}$. Essa terrível provação, em escala mundial, possui consequências dramáticas para a economia e para a sociedade, mesmo que o número de mortos (mais de 800000 no mundo, dos quais 170000 apenas nos Estados Unidos et 120000 no Brasil) tenha se mantido relativamente modesto se comparado às consequências demográficas de outras epidemias, como a "gripe espanhola" de 1918-1919 (50 milhões de mortos). Ela traz também consequências aos comportamentos quotidianos das populações, impondo "medidas de contenção" inéditas relativamente às tradições culturais de muitos países: os abraços estão proibidos, o porte de máscara em lugares públicos e nos ambientes de trabalho torna-se obrigatório. Em grande parte da Europa, especialmente, a obrigação do "confinamento" em casa, sob pena de sanção, foi duramente sentida. Some-se a isso, em alguns casos, um retorno à antiga prática da quarentena, transformada em uma "quatorzena"4, adaptada ao período de incubação do vírus. Nos países mais desenvolvidos, a epidemia surpreendeu os governos e as populações e revelou um grande despreparo. É necessário reconhecer que os riscos elevados de zoonose foram negligenciados, mesmo quando os meios científicos e as organizações nãogovernamentais alertavam há anos para os perigos da intensificação das relações entre homens e animais selvagens, como morcegos e pangolins. Imaginava-se, erroneamente, que epidemias desse tipo eram restritas aos "outros" (os africanos confrontados com o Ebola) ou aos séculos passados: a "gripe espanhola" na sequência da Primeira Guerra Mundial; a cólera, que matou milhões de pessoas na Europa, aproximadamente em 1830-1832; a varíola e o sarampo, que os Europeus exportaram no século XVI para o Novo Mundo, com as consequências catastróficas que se tornaram conhecidas através das populações ameríndias. E esqueceu-se, inclusive, da hecatombe anual das gripes sazonais - no fim das contas muito mais significativas que a do Covid-19.

Entre as epidemias passadas, as da peste, que assolou a Europa até 1720, mas que continua uma ameaça em certos países, como Madagascar, ocupa no imaginário 
coletivo um lugar privilegiado. Seu nome é, inclusive, comumente elevado à posição de metáfora do mal absoluto, como quando Albert Camus evoca, em 1947, no fim da Segunda Guerra Mundial, uma epidemia fictícia e não datada da peste em Oran, para significar, nas entrelinhas, a destruição causada pela "peste marrom" dos nazistas e de Vichy. O historiador constata, por sua vez, que a peste e seus retornos afetaram, apesar de longas interrupções, toda a "longa Idade Média", indo desde a Antiguidade Tardia (século VI) até a aurora da revolução industrial (século XVIII): a julgar apenas por esses limite cronológicos, já se pode notar que a peste se reveste de um valor sistêmico para as sociedades pré-industriais da Europa, durante esse "Antigo Regime" plurissecular que ela convida a considerar em todos os seus componentes, não apenas sanitários, mas também demográficos, econômicos, sociais, políticos, culturais ${ }^{6}$.

\section{Preliminares}

Distinguem-se, habitualmente, três grandes epidemias de peste que atingiram desigualmente a Europa.

1) A "peste de Justiniano", do nome do imperador que, na metade do século VI, lançou-se na reconquista, das mãos dos godos, do norte da Itália e que promulgou o célebre código de direito romano que leva seu nome. Trata-se de uma peste bubônica que, trazida do Oriente, atacou o Império Bizantino a partir de 541 e depois tomou o norte da Itália (Ravena), o vale do Rhône (de Marselha a Lyon) e o sul da Itália (Nápoles). Ela contou com aproximadamente quinze surtos, particularmente entre $558 \mathrm{e}$ 561 e em 590 em Roma, onde o papa Gregório Magno tê-la-ia repelido conduzindo uma procissão até o mausoléu de Adriano, no cume do qual teria milagrosamente aparecido o arcanjo São Miguel: daí o nome de Castelo de Sant'Ângelo que ele carrega desde então. Essa epidemia trouxe pesadas consequências, enfraquecendo o império e facilitando, assim, a expansão do Islam no século seguinte. Ela se prolongou, com intermitência, até 767.

2) A "peste negra" (Black Death), que surgiu na Europa em 1347-1348, e que em seguida retorna, em média, a cada cinco a dez anos até 1720 na Europa (Peste de Marselha) e em 1841 no norte da África. Também ela vem da China transportada para o Ocidente pelos mongóis, graças às trocas de todo tipo que animavam a Rota da Seda. 
Ela encontrou um intermediário favorável no entreposto comercial genovês de Caffa (Crimeia) - sitiado pelos mongóis - antes de tomar Constantinopla, em seguida os portos italianos e o de Marselha, onde chegou em $1^{\circ}$ de novembro de 1347. Ela apresentava uma forma principalmente bubônica, mas também pulmonar. Os surtos de peste sucederam-se durante três séculos, mas sua intensidade diminuiu progressivamente. Após o primeiro surto, o mais letal, de 1348 a 1352, que atravessou quase toda a Europa até atingir, finalmente, Moscou, a peste retornou em 1363, em 1374, em 1383 etc, e igualmente ao longo dos séculos XVI e XVII. Apenas no Reino da França, contam-se 26 surtos principais e 11 surtos secundários entre os séculos XIV e XVII, ou seja, uma a cada oito anos. Com exceção de 1348, as mais fatais aconteceram no século XVII: em 1606, em 1628-1629 (ano em que o reino teria perdido 1,6 milhões de habitantes, quase $10 \%$ de sua população) e, enfim, em 1668-1670. Depois disso, não se falou mais em peste até que ela retornasse com força, uma última vez, em 1720.

Observe-se, entretanto, que jamais, entre o fim do século XV e o início do século XVIII, a peste, contrariamente ao exemplo da varíola, atravessou o Atlântico. As razões, sem dúvida ambientais, ainda são mal elucidadas. No caso contrário, a "guerra microbiana" deixada às populações ameríndias teria sido ainda mais dramática, se possível.

De todos esses dados, é necessário ter que a peste nunca vem sozinha: ela é precedida ou acompanhada pela fome, pela instabilidade do clima (intempéries, precipitações, ou, ao contrário, longos períodos de seca), epizootia que devasta o gado, guerras (com as passagens de tropas que favorecem a difusão da doença). A fome, a guerra e a peste são os três flagelos indissociáveis contra os quais as populações cristãs suplicaram, ao mesmo tempo, à proteção divina. Assim, a peste negra de 1348 foi precedida, entre 1315 e 1318, por uma terrível fome devida às más colheitas, que possuíam, plausivelmente, causas climáticas ${ }^{7}$. Fome e peste inscrevem-se, numa perspectiva ainda mais geral, em uma inversão da conjuntura sensível desde o fim do século XIII e que assolou até aproximadamente 1470 ("a pequena era de gelo"), e ainda além dos séculos XVI e XVII: o ciclo dramático da estagnação demográfica, das más colheitas, da fome e das epidemias, ao qual se soma a guerra permanente (Guerra dos Cem Anos, Guerra de Religiões, Guerra dos Trintas Anos) explica, para além dos efeitos catastróficos da própria peste, que a Europa encontra-se, no século XVII, com 
uma população próxima à que tinha em 1300. A França, por exemplo, nunca ultrapassou durante todo esse período o número de 17 a 20 milhões de habitantes.

Esse longo período de estagnação e de crise, do qual as recorrências da peste são os fatores mais emblemáticos, contrasta com o período precedente, marcado por um desenvolvimento rápido de todas as forças materiais e humanas, entre o fim da peste de Justiniano (século VIII) e a Peste Negra (século XIV). Estima-se que a população europeia pôde triplicar entre 800 (época de Carlos Magno) e 1348. Fatores climáticos massivos, ligados à irradiação solar, às emissões vulcânicas (intensas entre 1167 e 1284), às oscilações das massas de ar dos oceanos Pacífico e Atlântico (o fenômeno El Niño) permitiram, durante quatro a cinco séculos, um aquecimento climático e uma modificação da pluviosidade que se mensura graças à dendrocronologia (leitura dos tree-rings ou anéis nos troncos das árvores), às perfurações de zonas glaciares ou ainda às cheias do Nilo (conhecidas anualmente de 641 a 1469). Essas mudanças climáticas favoreceram a extensão de culturas alimentares e, consequentemente, o desenvolvimento demográfico de uma sociedade quase exclusivamente rural. Ao contrário, a população, por volta de 1450 , não seria superior à metade do que ela tinha sido antes da Peste Negra ${ }^{8}$.

3) A Peste da China: vinda do Yunnan, ela flagelou, entre 1850 e 1940, a Ásia (especialmente a Índia, onde fez 10 milhões de mortos) e Madagascar. Ela atingiu o mundo ocidental apenas marginalmente, limitando-se a certos portos da Europa e da América. Mas seu papel não é menos importante para história da peste, porque permitiu a Alexandre Yersin descobrir, em Hong Kong, em 1894, o bacilo que é a sua causa, bem como o papel das pulgas e dos ratos na sua transmissão.

\section{Interpretações}

Algumas palavras sobre palavra "peste": ela deriva do latim pestis que, longe de designar originalmente uma doença específica, designa toda sorte de calamidade. Exatamente o mesmo se diz da palavra grega leimos, utilizada por Tucídides (430-426 d.C.) para descrever minuciosamente o "flagelo" que atingiu Atenas vinte e cinco anos mais cedo9: uma epidemia catastrófica que sobreveio ao mesmo tempo que a guerra do Peloponeso e que os eruditos erroneamente chamaram de "Peste de Atenas", quando, na 
realidade, tratava-se plausivelmente do tifo, vindo da Etiópia pela Síria e pela Ásia Menor. De qualquer modo, esse acontecimento permitiu, da parte do grande historiador grego, uma descrição tão dramática quanto detalhada, da qual se lembrarão, bem mais tarde, os autores que quererão retratar a verdadeira peste. Os textos medievais, quanto a eles, utilizam, para designar a Peste Negra, as palavras genéricas mors, morbus, mortalitas ou seus equivalentes vernaculares (como mortalité, em francês). Entretanto, a partir de 1348, as palavras peste e pestilência tendam a tomar um sentido específico, designando apenas a peste verdadeira.

Tanto na Antiguidade Tardia como na Idade Média e na Época Moderna, a peste foi atribuída, em primeiro lugar, à corrupção do ar ao mesmo tempo que a um castigo divino merecido pelos homens por causa de seus pecados. Tais explicações harmonizavam-se bem com os princípios fundamentais da medicina tradicional, que se baseava na noção de equilíbrio interno (entre os humores, o quente e o frio, o úmido e o seco) e externo (as correspondências entre o microcosmo e o macrocosmo) do corpo humano: é assim que o temperamento sanguíneo (quente e úmido) era tido como mais vulnerável à peste que os temperamentos colérico, fleumático ou melancólico. Entretanto, a partir do fim da Idade Média, outras concepções apareceram, incluindo a possibilidade de contágio entre homens. Em 1626, o jesuíta matemático Athanase Kircher, cujo saber é enciclopédico, fez avançar a noção de "contagium vivum” para sugerir que qualquer "animalcule" observado por ele em seu microscópio poderia ser responsável pela peste. Assim, concepções “contagionistas” progrediram pouco a pouco, mas sem destronar as concepções tradicionais (corrupção do ar e castigo divino) defendidas pelas autoridades médicas, civis ou religiosas. Essas novas concepções antecipavam, em certo sentido, as descobertas de Pasteur e, mais especificamente, de Yersin. Porém, deve-se destacar que nunca ninguém, antes desse último, questionou-se sobre o papel das pulgas e dos ratos: esses insetos e roedores eram deveras comuns e familiares para que os homens, acostumados a apanhar uns e a catar os outros, pudessem suspeitar que eles desempenhassem um papel tão mórbido!

Então, a ciência moderna finalmente possibilitou a identificação da causa da doença da qual já se começara a proteger-se, empiricamente, nos séculos passados. Distinguem-se duas formas de peste: a peste bubônica, a mais frequente, devida à mordida de uma pulga (ou de um piolho) transportada pelo rato negro (rattus rattus). 
Essa forma da peste, caracterizada pela aparição de bubões na virilha ou nas axilas, em seguida de antraz cutâneo em todo o corpo, bem como febres altas e alucinações, oferece, no entanto, possibilidades de cura. Não é certo que a eliminação do rato negro pelo rato cinza no século XVIII tenha tido papel significativo no desaparecimento da peste na Europa. A outra forma da peste é a peste pneumônica, que se transmite diretamente de homem para homem e que é mortal em todos os casos.

\section{A peste na Europa de 1348 a 1670}

De 1348 a 1352, a Peste Negra cobriu a Europa inteira de maneira fulgurante, até atingir Moscou em quatro anos, deixando incólumes atrás de si apenas raras regiões: alguns isolados nos Bálcãs (porque ela passou pelo mar), em alguns massivos montanhosos (como os Pirineus e o Massivo Central, na França) ou nas zonas do interior de algumas cidades, como Bruges, que, ao contrário, foi duramente atingida. A sorte também teve participação: um navio pronto para zarpar com destino à Islândia ficou no porto porque toda a sua tripulação havia sucumbido; salva provisoriamente do flagelo, a grande ilha do Norte esperou até 1402 para sofrer com a peste pela primeira vez.

A progressão da epidemia não ultrapassou a média de dois quilômetros por dia: é pouco, comparado com a distância percorrida em um dia de caminhada ou mais rapidamente a cavalo, ou com a velocidade na qual se pode descer um rio a bordo de um barco mercante. Mas deve-se levar em conta as condições concretas dos deslocamentos ao longo dos caminhos ou das vias navegáveis e as chances desiguais de encontro com outros viajantes ou com populações locais. A peste propagava-se mais rapidamente descendo um rio (por exemplo o Garonne, de Toulouse a Bordeaux) que subindo o rio (a exemplo do Rhône entre Marselha e Lion, por onde ela fez seu primeiro avanço na Europa Ocidental). 


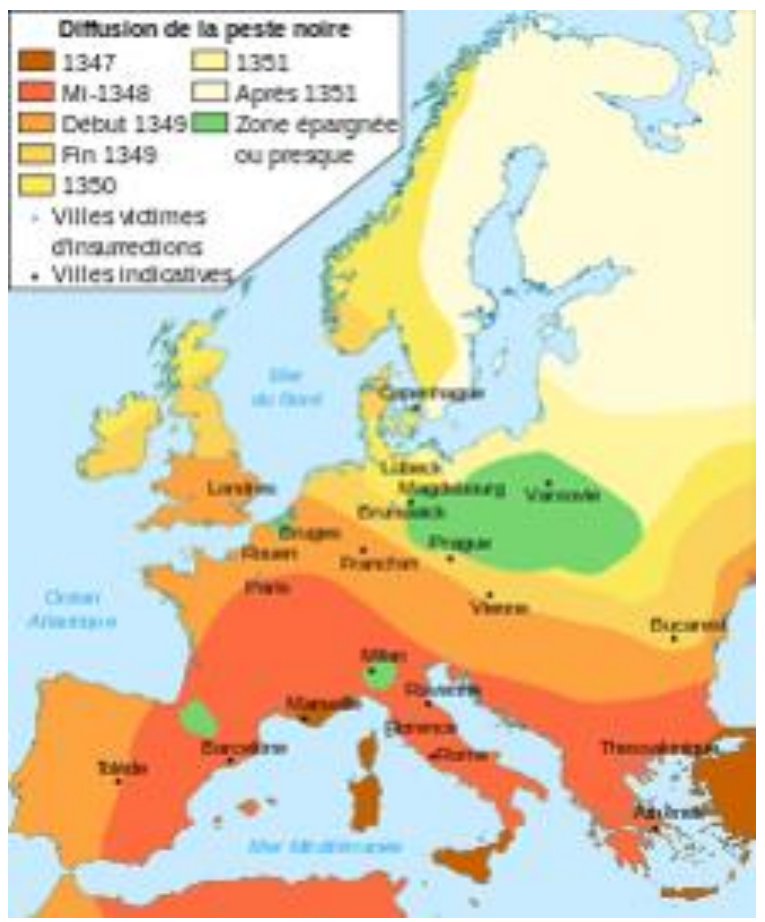

Figura 1: Mapa da disseminação da epidemia de peste em 1348-1352

De qualquer forma, a hecatombe foi imensa, de tal forma que é difícil de imaginar. Guy Bois, historiador da Normandia dos dois último séculos da Idade Média, falava de um "Hiroshima na Normandia"10: com efeito, a metáfora da bomba atômica não é forte demais para nos fazer avaliar uma catástrofe tão brutal e fatal. Porém, na falta de estatísticas, ficamos limitados a estimativas muito aproximativas, tirando o melhor proveito possível de fontes fragmentárias e variadas.

$\mathrm{Na}$ falta de recenseamentos da população, dispõe-se, às vezes, excepcionalmente, de números plurianuais que permitem avaliar a mesma população antes e depois da passagem da peste: é o caso (bem conhecido dos historiadores) da paróquia de Givry, na Borgonha, graças às contas paroquiais, que registraram excepcionalmente os direitos pagos ao pároco pelos casamentos e pelas sepulturas durante quase todos os anos entre 1334 e 1357. Inicialmente, a paróquia contava talvez 2000 habitantes, e lá se faziam anualmente 28 ou 29 enterros por mês. Durante os quatro meses de julho a outubro de 1348, o número de enterros aumentou, em determinados dias, para 24! A peste ceifou no total 600 pessoas, ou seja, um terço da população. Os números são comparáveis na paróquia de Saint-Nizier de Lyon, que contava 3000 ou 4000 habitantes antes da peste. Registravam-se lá, habitualmente, entre 80 e 85 enterros por mês. Entre abril e junho de 1348, contam-se 900 a 1000 mortes, 
dentre as quais entre 300 e 350 crianças: também lá, as perdas atingem 20 ou $30 \%$ da população.

Outras séries de números estão igualmente disponíveis: é o caso do número de testamentos passados perante um notário nas vésperas da epidemia. Em Londres, por volta de quarenta testamentos eram concluídos a cada ano; em 1349, contam-se 360 . Na paróquia de Saint-Germain-l'Auxerrois, em Paris, passa-se de uma média anual de 1 a 4 testamentos a 50 testamentos em um único ano, 1348-1349. Isso diz muito, se não das mortes comprovadas, ao menos do medo de morrer em breve.

Localmente, outras séries documentais podem nos informar, como as listas de "domicílios" (feux ou foyer, em francês) dependentes de uma senhoria fundiária. Por convenção, os historiadores estimam que um domicílio abriga cinco pessoas sob um teto. Vejamos um exemplo privilegiado, que concerne um vilarejo do sul da França que conheço bem11 : os paroquianos do vilarejo de Castagnols (atualmente Vialas) dependiam, para a terra que cultivavam, de dois senhores fundiários: o senhorio de Montclar (cujas ruínas do castelo ainda dominam sobre a cidade) e o priorado canônico de Gourdouze (estabelecido mais alto na montanha sobre a borda do planalto do Lozère). O primeiro senhor mandou elaborar duas listas de seus servos e vilões e de seus tributos feudais: uma em 1337, antes da peste (são enumerados 54 domicílios, isto é, aproximadamente 250 habitantes), e outra em 1357, depois da peste: contam-se apenas, nesse momento, 41 domicílios, ou seja, 190 pessoas aproximadamente. Por sua vez, o priorado de Gourdouze contava em sua dependência, em 1347, às vésperas do flagelo, 115 domicílios, aproximadamente 550 habitantes; devido à falta de lista de servos e vilões depois da passagem da peste, ignoram-se nesse segundo caso quantas pessoas sobreviveram, mas pode-se deduzir um número provável a partir lista de Montclar. No total, a população do vilarejo possivelmente passou de um mínimo de 900 a 1000 habitantes a somente 450 , isto é, uma perda de $40 \%$ !

Observemos, contudo, que esse abismo demográfico foi-se preenchendo progressivamente nas décadas seguintes, antes de se estabilizar em torno de 1500 habitantes durante todo os séculos XVI a XVIII12.

Se multiplicarmos as observações locais, chegamos à assustadora conclusão de que a Europa perdeu, em quatro anos, um terço de sua população. Depois disso, os retornos periódicos da peste durante três séculos continuaram a atingir as populações 
sem dar-lhes a trégua necessária para uma recuperação sustentável. Mas devem-se levar em consideração as diferenças geográficas; a oposição entre, de um lado, as cidades densamente povoadas e mais vulneráveis e, do outro, o interior, especialmente quando as moradias eram dispersas. Em algumas cidades, como Veneza em 1405, Milão em 1576-1577, Lyon e Digne em 1629, observam-se taxas de mortalidade superiores a 50\%! Muitas cidades sofrem, por isso, um declínio durável, como Florença, Sevilha, Barcelona. Outras, é verdade, recuperaram-se rapidamente, como Londres, que passa, no século XVII, de 200000 a 400000 habitantes.

Grandes foram também as diferenças sociais, pois os mais ricos tinham a possibilidade de refugiar-se em residências isoladas no interior, a exemplo do grupo de sete moças e três rapazes evocado por Giovanni Boccacio em 1353, no prólogo do Decamerão: enquanto toda a sociedade florentina é posta a baixo pela epidemia, enquanto os cadáveres acumulam-se nas ruas por falta de sepultura e enquanto sucumbem também os porcos que remexeram, com seus focinhos, a manada de vítimas, uma porção despreocupada de aristocratas na flor da idade busca abrigo em uma casa de campo do contado para contarem histórias agradáveis... Essa ficção literária não está distante da realidade, pois, alguns anos mais tarde, em 1362, quando a peste estava de volta, Francesco Petrarca escreveu a seu amigo Boccacio para convidá-lo a deixar a cidade com ele.

Outras narrativas feitas no momento nos permitem igualmente apreciar as reações dos contemporâneos. Gabriel de Mussis (+1356), atuante em Piacenza, compõe, em latim, uma Historia de Morbo, na qual descreve, em termos dramáticos, o sítio a Caffa (onde os mongóis teriam lançado, para dentro da cidade genovesa, por cima das muralhas, cadáveres infectados) e as devastações da epidemia na Sicília. Mais ao norte, o abade de Saint-Martin de Tournai, Giles le Muisis (+ 1353), compila várias crônicas muito preciosas entre 1347 e 1351. As miniaturas que ilustram certos manuscritos de sua obra mostram o acúmulo de caixões levados na maior desordem até o cemitério e os massacres dos judeus acusados de propagar a epidemia. 


\section{A peste de Marselha em 1720}

Após 1670, a peste parecia desertar a França. Mas ela voltou com força meio século mais tarde, pela última vez. No dia 24 de maio de 1720, chega do Levante, no porto de Marselha, o Grande Saint-Antoine, que já fez escala em Trípoli, Livorno e Toulon. O proprietário da carga, um magistrado marselhês influente, subornou os oficiais do porto para que encurtassem a quarentena da tripulação e autorizassem o descarregamento rápido do navio. Porém, os lotes de seda oriental descidos para o cais estão infestados de pulgas transmissoras da peste. A epidemia espalha-se pela cidade, primeiro lentamente, em seguida ela se faz conhecida no dia 28 de junho. Com o calor do verão e após chuvas torrenciais, ela explode no dia 21 de julho. Pânico geral: 10000 pessoas saem da cidade e fogem para a Provença, onde a epidemia se propaga. Um cordão sanitário é instituído no dia 4 de agosto em volta da cidade, mas muitos fugitivos conseguem atravessá-lo. Na cidade, as casas contaminadas são fechadas e fumaçadas, e suas portas marcadas com uma cruz vermelha. Em julho, contam-se cem mortos por dia, que os "corvos"13, que são frequentemente condenados a trabalhos forçados libertos para esse fim, devem recolher para sepultar, correndo o risco de serem eles próprios contaminados. Em agosto, o número quotidiano de vítimas atinge 400; em setembro, ele chega a 1000. No total, a peste de 1720 terá matado na região 120000 pessoas, dos quais 50000 em Marselha.

Esse retorno dramático da epidemia teve, em todo o reino e além dele, um forte impacto. O rei Luís XV envia uma delegação de médicos, conduzida pelo doutor Chicoyneau, decano da faculdade de medicina de Montpellier. Por precaução, ele reveste a roupa protetora desenvolvida no século anterior pelo médico do rei Luís XIII, Charles Delome, e que se distingue especialmente por seu longo bico contendo condimentos, tabaco e pólvora. Uma gravura alemã revela esse estranho traje, sinal do impacto distante da Peste de Marselha. 


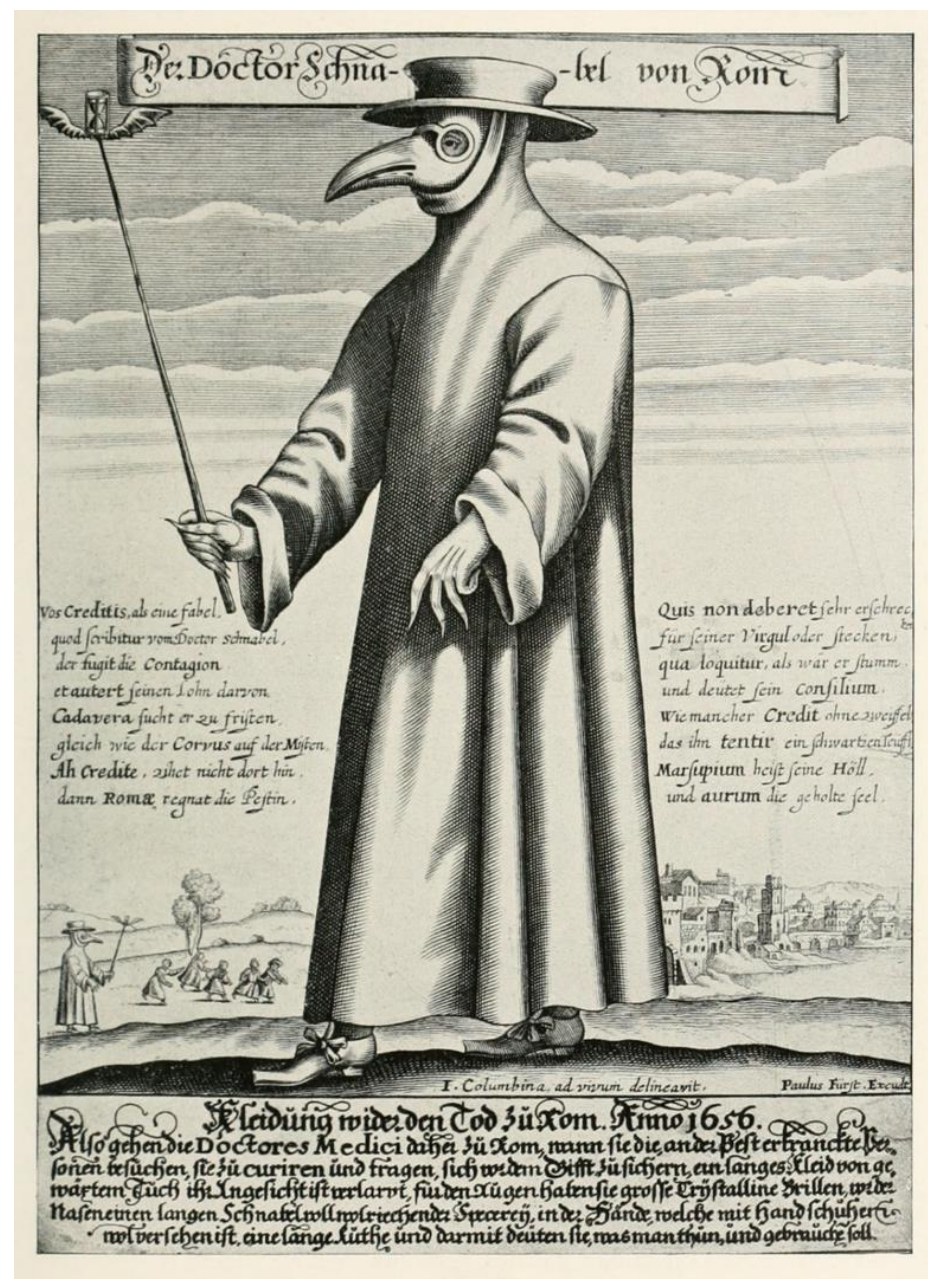

Figura 2: O "Doutor-Bico" Chicoyneau

Em 1722, ela inspirou também ao jornalista e romancista inglês Daniel Defoe uma notável obra: seu Diário do ano da Peste (The year of the Plague)14. Essa descrição da catástrofe reunia as informações coletados dois anos antes de Marselha e as lembranças da grande peste londrina de 1664-1665, que matara 70000 pessoas. Defoe previra a epidemia de 1720, observando em seu jornal, Review, desde o dia 23 de agosto de 1712, que a peste progredia na Turquia, na Hungria, na Polônia, na Suécia, na Alemanha, na Dinamarca e que ela ameaçava atacar, em pouco tempo, os confins mais ocidentais da Europa.

Localmente, um dos problemas mais urgentes era imposto pela acumulação de cadáveres em putrefação, que não se conseguia mais enterrar. O Cavaleiro Nicolas Roze, comissário do bairro de Rive-Neuve, conseguiu que eles fossem tirados por soldados e galerianos - coveiros improvisados -, os quais morreram durante o trabalho, à exceção de cinco, dentre os quais o Cavaleiro Roze. 
Durante esse tempo, a peste espalhava-se pelos arredores: Cassis, Aix, Toulon, Apt, Digne, Arles são atingidos. Na Ciotat, onde o governador quer autorizar a entrada da tropa, as mulheres suspeitam que os soldados podem trazer consigo a peste e formam uma barreira, agitando diante deles seus filhos. Entre Avignon e Sisteron, as autoridades levantam o Muro da Peste, construído de pedra, duplicado por um fosso e protegido por soldados armados que têm ordens de prender, se necessário a força, os fugitivos.

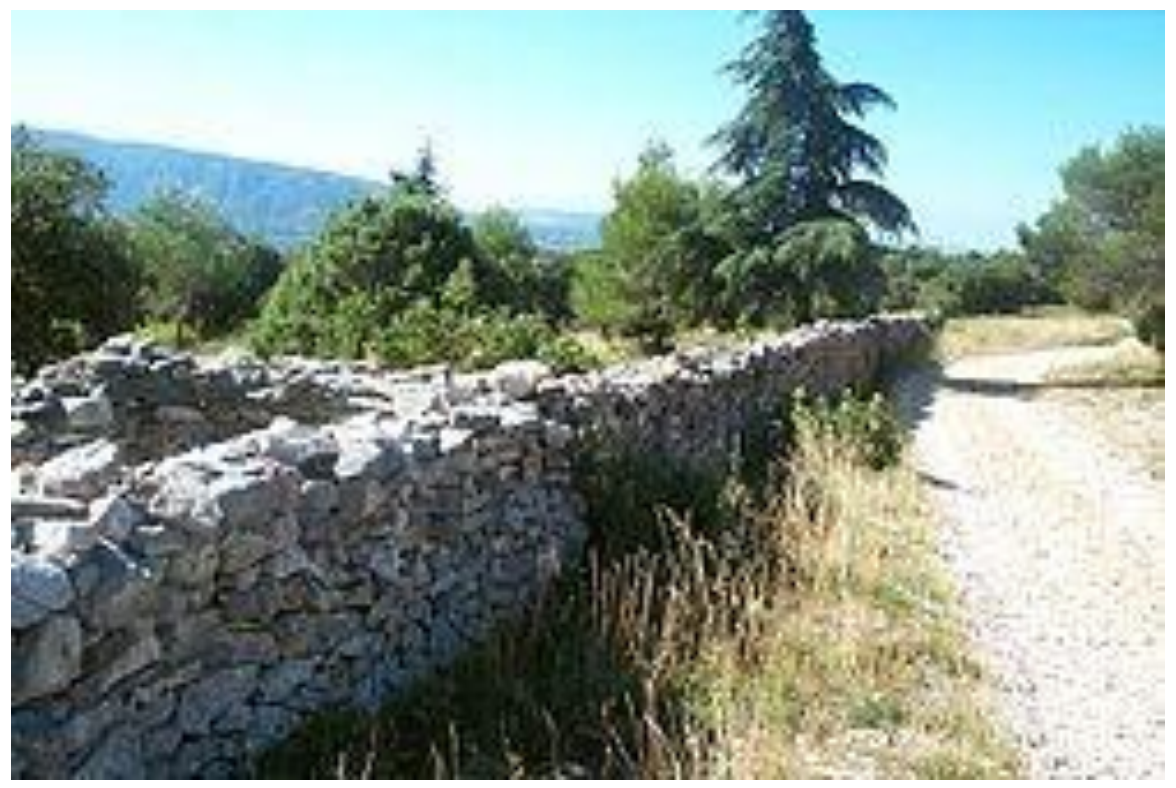

Figura 3: Vestígios do Muro da Peste na Provença

Em outros lugares, contenta-se de dispor "fileiras" de soldados, a fim de impedir os deslocamentos de uma região a outra. A "fileira" principal percorre toda a margem Rhône, mas ela não consegue isolar a peste na Provença, na margem esquerda: ela atravessa o rio e difunde-se pela margem direita, no Languedoc, nas dioceses de Nimes, de Alès, de Uzès e até de Mende, mais ao norte. 


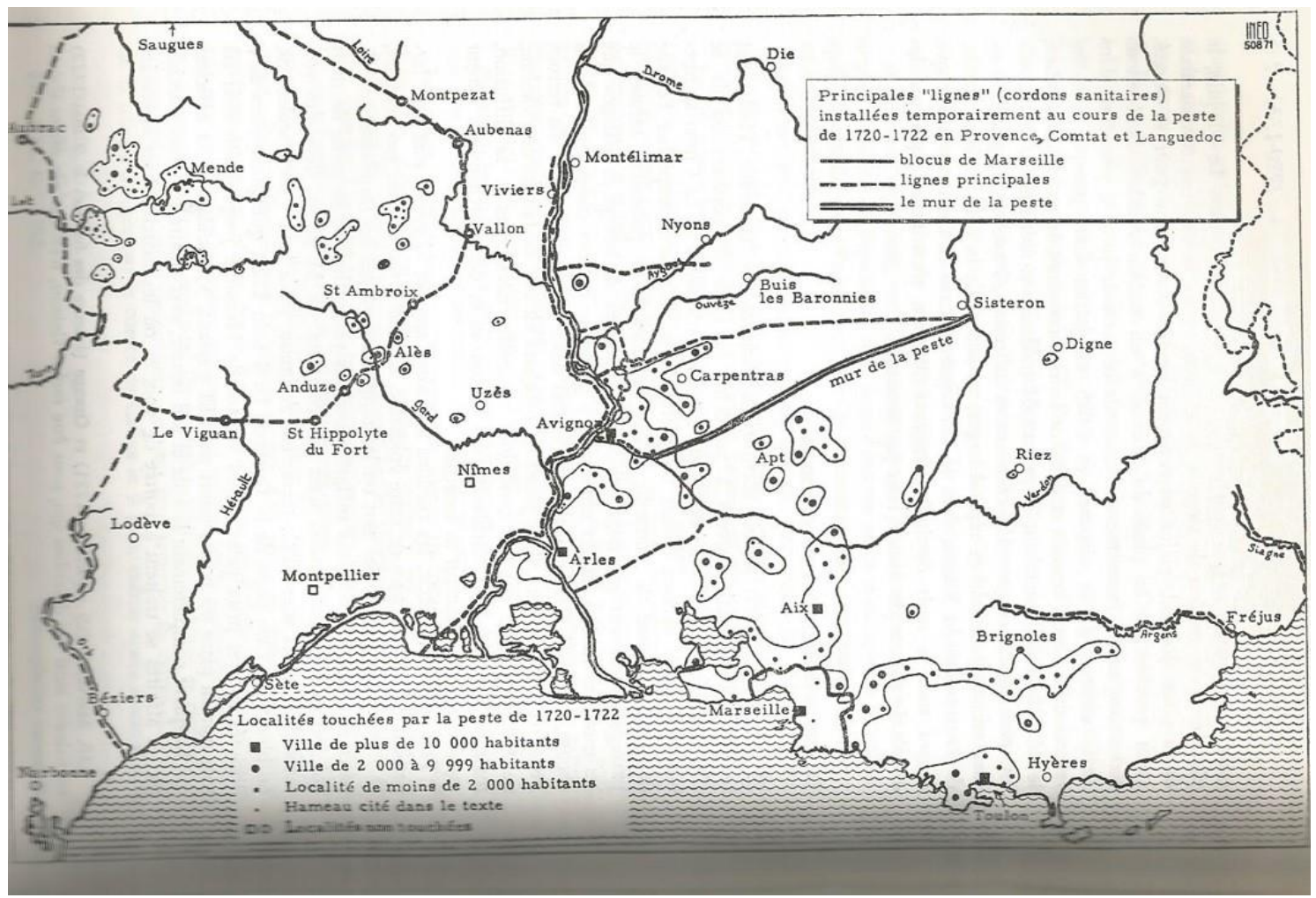

Figura 4: Mapa da disseminação da epidemia na Provença e no Languedoc, segundo J.-N. Biraben, volume 1, p. 246

É em escala micro-local que se observam melhor os perigos da peste: as cidades de Mede, Marvejols, La Canourgue (no atual departamento da Lozère) são seriamente atingidas: elas perdem cerca de um quarto de seus habitantes. Ao lado de La Carnougue, a população do vilarejo de Corréjac, onde um trabalhador forçado fugido de Marselha lamentavelmente refugiou-se, é inteiramente dizimado, e as casas são incendiadas para tentar eliminar a pestilência. Em contrapartida, as cidades próximas de Villefort e Concoules, apesar de situadas no eixo da Regordane (a estrada de Nimes a Paris), perderam, apenas, $1 \%$ de sua população. Bem perto de lá, Genolhac (1100 habitantes) lamenta, ao contrário, 250 mortos ( $22,7 \%$ da população). Mas a epidemia poupa o vale vizinho de Luech, onde o vilarejo de Vialas, que foi tão cruelmente atingido em 1348, foi desta vez salvo. Vê-se, seguindo as micro-redes das vias de comunicação, sua frequentação, a densidade da população e o grau de dispersão da área habitada, e até mesmo os acasos da contaminação, que as devastações da epidemia variam enormemente de um lugar para outro, mesmo a pouca distância. 


\section{Os comportamentos coletivos diante da peste}

A peste é o mal absoluto. Eis por que ela é compreendida como o castigo que Deus inflige aos homens para puni-los de seus pecados. Ela é a provação catártica que, para alguns, precede o combate final entre as forças do Bem e do Mal, a vinda do Anticristo, cuja derrota final permitirá o retorno do Cristo e o Juízo Final, como predito no Apocalipse15. Por essa razão, os cristão devem, devido à peste, preparar-se para o cumprimento escatológico convidando ao arrependimento antes de sucumbir: a peste encoraja as procissões de penitentes e flagelados e a criação de confrarias (como as dos Penitentes Brancos e dos Penitentes Negros), colocados sob o patronado da Virgem Maria ou dos principais santos "anti-peste": São Sebastião (cujas flechas do martírio simbolizam o ataque da peste), São Roque (que traz à coxa uma ferida similar ao bubão da peste) ou Santo Antônio, o Ermita (tradicionalmente invocado contra os "Maus dos Ardentes" ou "Fogo de Santo Antônio").

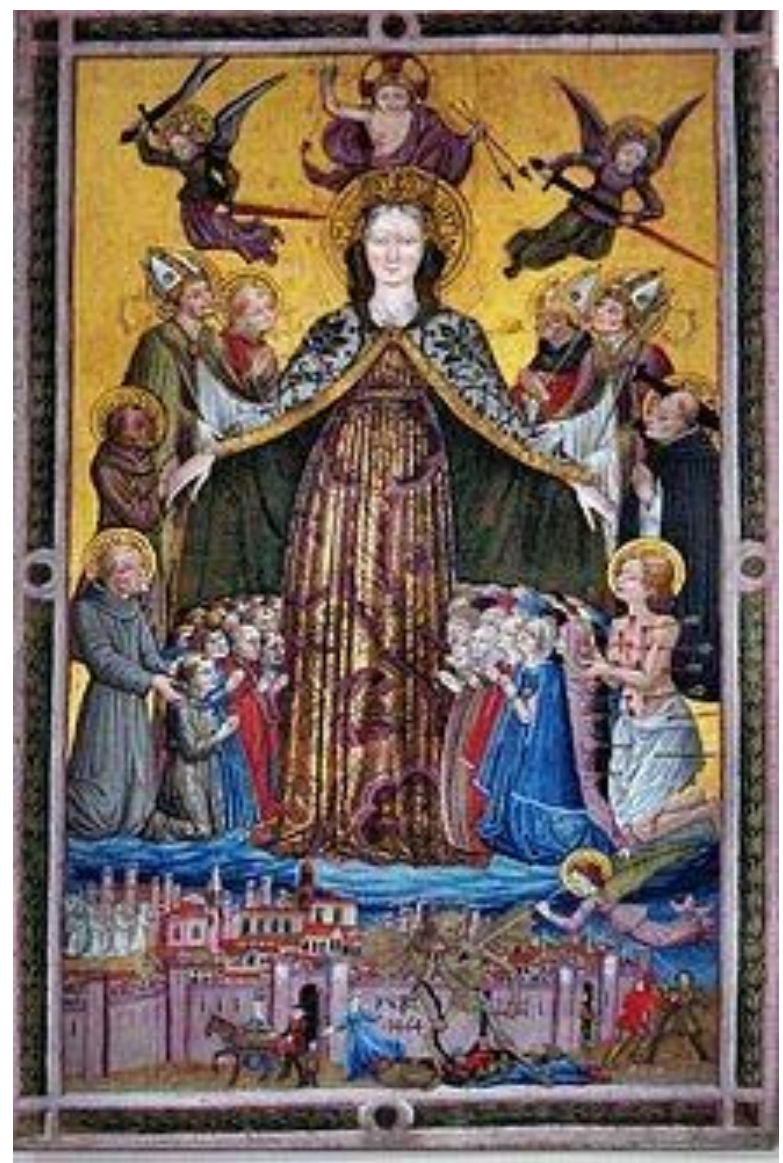

Figura 5: A Virgem de Misericórdia. Estandarte de procissão pintado por Beneditto Bonfigli, 1464, Perugia, Galleria Nazionale 
$\mathrm{Na}$ época moderna, as novas experiências da peste conduziram ao acréscimo ao catálogo de outros santos protetores, como São Carlos Borromeu. Depois da peste de 1629, que teria matado "dez mil" habitantes da cidade de Puy, os cônsules da cidade fizeram um voto solene, no dia 22 de abril de 1630, para agradecer a Deus e à "Gloriosa Virgem, sua boa senhora e matrona" de tê-los liberto do "mal da peste": eles ofereceram à catedral duas grandes pinturas, que ainda estão lá preservadas; em uma, os cônsules são apresentados vestidos de vermelho, em oração diante da estátua da Virgem Negra do Puy; na outra, onde uma cartela explicita o voto dos cônsules, figura a longa procissão de todas as "ordens" da cidade, que acompanham a estátua milagrosa em procissão.

Em 1348, a natureza súbita e passiva da Peste Negra levou também à designação de bodes expiatórios. Já no passado, as catástrofes coletivas, como a fome, a morte inexplicada do gado ou outras epidemias, levaram as multidões a acusarem os pobres, os mendigos, algumas mulheres suspeitas de magia negra e, de maneira geral, todos os que não se beneficiavam da proteção de um sólido sistema familiar e social, de terem envenenado os poços ou lançados uma maldição. Desde os tempos das cruzadas, os judeus tinham sido mais de uma vez objetos de acusação de crimes rituais. Desta vez, eles são tidos como responsáveis pela peste e massacrados nas cidades onde formam uma parte não negligenciável da população e onde suas atividades lucrativas de usurários suscitavam tradicionalmente hostilidade ou inveja. Os reinos da França e da Inglaterra não são afetados, pois as comunidades judaicas já tinham sido de lá expulsas. Em contrapartida, as cidades do Reno e do sudoeste da Alemanha conheceram assustadoras cenas de violência. Em Estrasburgo, em 14 de fevereiro de 1349, de 1884 judeus, 900 são massacrados e queimados. Na Francônia, na região de Würzburg, um açougueiro de nome Rindfleisch (sic) solta contra os judeus um bando de assassinos sem piedade16. Geralmente, as autoridades urbanas, eclesiásticas ou soberanas (das quais os judeus são tradicionalmente considerados os "servos do Tesouro" (Kammerknechtschaft) e que elas protegem para tirar ainda mais proveitos fiscais e monetários), buscam frear esses comportamentos. O papa acolhe os judeus em Avignon, como constata Thomas Platter, jovem médico originário de Basileia, formado pela Universidade de Montpellier, quando ele visita a cidade em 1598: ele traz o rumor segundo o qual os judeus, que não consumiam a carne do traseiro do boi, vendem-na aos cristãos depois de tê-la contaminado e "amaldiçoado para que os cristãos engulam a 
morte bubônica na virilha. Todos os judeus que se converteram à fé cristã atestaram esse fato, unanimemente"17. Mesmo em Avignon, suspeita-se que os judeus espalharam a peste. Outro refúgio é a Polônia do rei Casimiro II, cuja política de acolhimento inicia um processo de refúgio das comunidades judaicas na Europa central que terminará tragicamente com a Shoa.

A peste obriga também a tomada de medidas gerais de força policial e contribui, assim, com o desenvolvimento administrativo dos Estados e das cidades no final da Idade Média. A partir do século XIV, as cidades italianas tomam medidas sanitárias de interesse público. Em Veneza, são nomeados, em 1348, três "provveditori de saúde”. O primeiro decreto preconizando medidas contra a peste em escala de todo o reino foi promulgada pelo rei da França, João, o Bom em 1351. Em 1429, é criada, em Barcelona, uma comissão ou cerca destinada à pesquisa sobre os infectados. Em 1497, o Parlamento de Paris interveio pela primeira vez na área sanitária. A partir de 1383, em Marselha, emitem-se aos viajantes vindos de cidades não contaminadas "carteiras de saúde". Em 1532, Londres inaugura a prática das bills, permitindo aos indivíduos atestarem que não são contagiosos. Essa prática é regularmente observada no Languedoc no fim do século, como testemunha Thomas Platter em 1598: ele não sai de uma cidade sem solicitar uma "carteira de boa saúde" impressa e certificada pelas autoridades de Nimes, Uzès ou Montepellier18. Quando da epidemia de cólera na França em 1932, falar-se-á, similarmente, de "carteiras"19. Em 1668, um decreto real resolve sobre a limpeza de Paris, regulamentando os depósitos de lixo, limitando a poluição dos curtumes e dos açougues, proibindo os barbeiros de dar aos porcos, como bebida, sangue humano recolhido das feridas.

Outras medidas visando à instauração do que se chama atualmente, como comprova o Covid-19, das "medidas de contenção": a prática da quarentena, nos portos, vale-se de uma ideia já presente no século VI a.C., no trabalho do médico grego Hipócrates, para quem uma doença aguda manifesta-se, no máximo, durante quarenta dias, prazo além do qual tratar-se-ia de uma doença crônica. Esse período de quarenta dias encontrava reforço na sociedade cristã, uma vez que o Cristo jejuou todo esse tempo no deserto; a Igreja seguiu o exemplo instituindo a Quaresma (do latim quadagesima: quadragésima), período de penitência de quarenta dias antes da festa da Páscoa. A primeira quarentena marítima ou "quaranta" foi decretada no porto de 
Raguse em 1377; Veneza, Marselha, Barcelona seguiram rapidamente o exemplo. Em complemento a essas medidas, foram criados lazaretos (o primeiro é atestado em Veneza em 1374), destinados a isolar as doenças do resto da população: eles rapidamente se revelaram aterrorizantes matadouros em massa.

Outra medida era o "evitamento", em outras palavras, o estrito fechamento de uma cidade contaminada, sendo proibida a entrada de pessoas saudáveis. Inversamente, uma cidade infestada, como será o caso de Marselha, era isolada do interior pour uma "fileira" de defesa solidamente policiada. Na Savóia, em 1575, decretou-se o que nós criamos o hábito de nomear "confinamento": foi proibida a circulação de pessoas em tempo de epidemia. Em outros lugares, houve fechamento de escolas, e as assembleias foram proibidas. Em Angers, "o beijo da paz" é proibido nas igrejas. Apenas as autoridades soberanas tinham o poder de criar "fileiras" e de confiá-las à guarda dos soldados. Essa medida é experimentada em Paris por Colbert antes de se generalizar, mas sua eficácia, já vimos, era aleatória. Os dissidentes corriam risco de ser fuzilados. Em 1722, o escritório de saúde de Fréjus decretou que seja fuzilado o general Bonaparte, porque ele se recusara a submeter-se à quarentena. Ele escapou dela, o que não deixou de ter consequências para a história geral...

Outras medidas tinham natureza mais propriamente terapêutica. Os médicos são convocados e, frequentemente, muito bem pagos em razão dos ricos que corriam. Prescrevem que os doentes sejam trancados em suas casas, ou em "cabanas" ou "barracas", como decreta o papa Clemente VI em Avignon a partir de 1348; em outros lugares, esses recintos improvisados são chamados de "chabotes", "hobettes" ou simplesmente "tendas", caso sejam cobertas por uma simples lona. Além dos lazaretos já mencionados, criam-se novos hospitais: em Paris, nas periferias norte da cidade, o rei Henrique IV funda o Hospital São Luís em 1607. Em Lyon, três novos hospitais são criados no confluente do Saone e do Rhone, para que os doentes possam chegar de barco. Antigos leprosários (que já não serviam a muita coisa, tendo em vista o desaparecimento da doença no final da Idade Média) são convertidos em hospitais para os contaminados. É difícil dizer dos verdadeiros cuidados dados aos doentes além da assistência espiritual. Perfurar um bubão com um golpe de bisturi não era suficiente para curar a peste. 


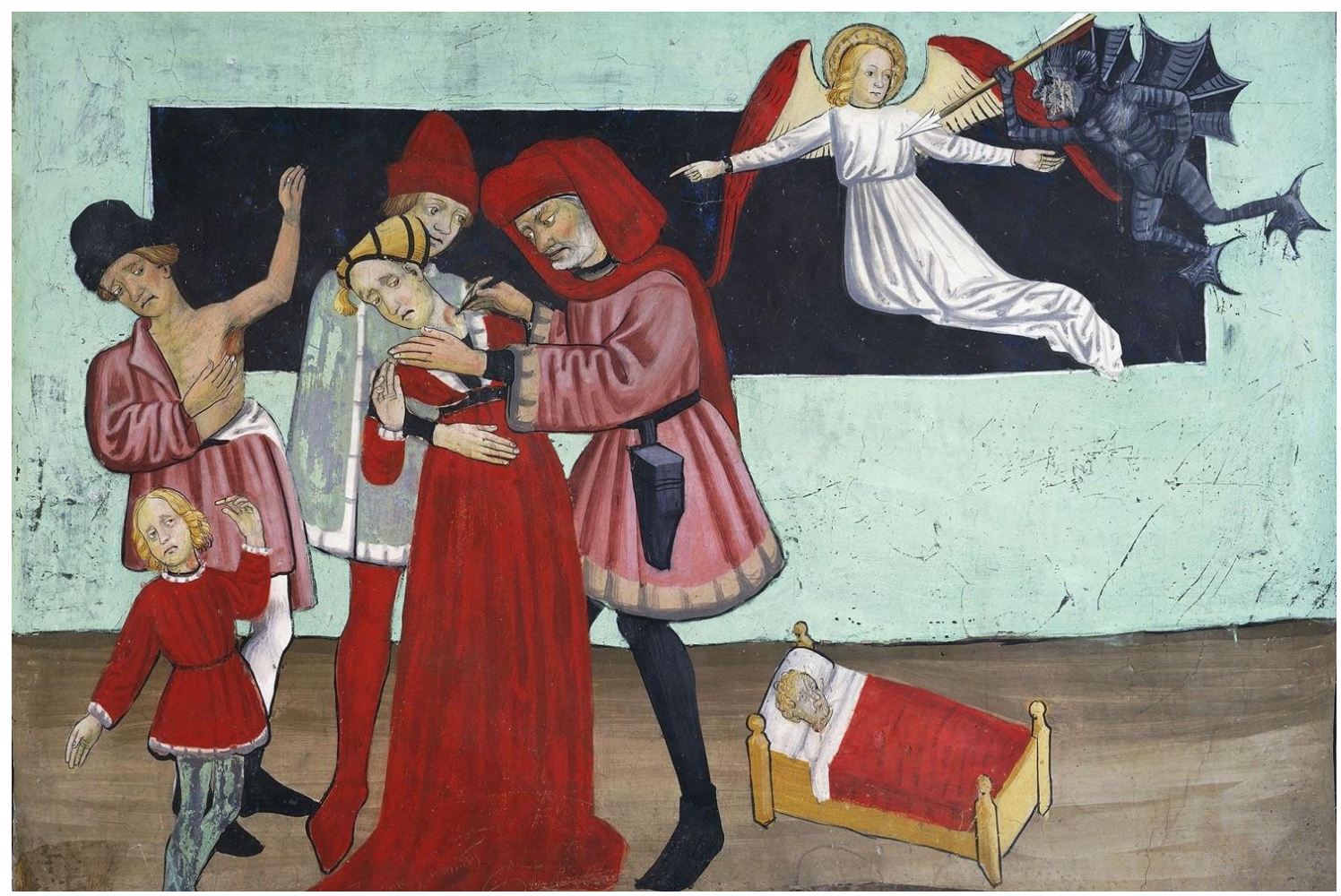

Figura 6: Um médico perfura os bubões em uma família vítima da peste. Afresco do século XV, capela São Sebastião de Lanslevillard, Savóia

O problema é que a aglomeração facilita a contaminação. As taxas de mortalidade são assustadoras e ninguém as ignora: os doentes preferem ficar em casa para morrer. Mas, nesse caso, eles contaminam a família inteira. Nas cidades, trabalhavam os "perfumadores", “desinfectadores", “esfregadores" ou "arejadores", atestados desde o século XVI. Eles proviam incensos, enxofre, pólvora de canhão, arsênico, antimônio e outras substâncias suscetíveis de purificar o ar para barrar a doença. Até mesmo as missivas são perfuradas para que se possa infundir perfumes nelas antes de serem abertas. Nos séculos XVII e XVIII, o medo do contágio tem participação no novo entusiasmo pelo tabaco, que os homens e também as mulheres fumam em pequenos cachimbos holandeses feitos de terra. Os médicos cobrem suas mãos com folhas de tabaco antes de tocar os bubões. De resto, a ligação entre tabaco e medicina não se limita ao caso da peste, porque, na mesma época, tanto em Londres como em Paris, pensa-se poder reanimar os afogados infundido-lhes fumaça de tabaco no ânus $20 . .$.

Um dos pontos mais cruciais permanecia a coleta e o enterro dos cadáveres, que deveriam ser retirados das casas e recolhidos ou, antes, "enganchados" no meio da rua. Os "corvos" ou "enterradores" são encarregados dessa sinistra missão, enquanto 
mulheres "costuram os mortos", ou seja, confeccionam sudários. Para não criar pânico, é proibido tocar os sinos nos enterros, que acontecem, de preferência, à noite. Incinerações em massa e fossas comuns são necessárias quando a epidemia atinge os ápices. A convulsão das práticas funerárias tradicionais chama, desde 1348, a atenção dos contemporâneos. Ela levará a termo novas práticas e, em primeiro lugar, no início do século XIX, a relegação dos cemitérios para fora das cidades.

A peste também estimulou novas práticas administrativas, encorajou o recenseamento das populações, contribuiu com o desenvolvimento das estatísticas públicas em todas as áreas: a contagem dos mortos ou dos órfãos é apenas um aspecto do recenseamento de toda a população, da estimativa de seus recursos, do cálculo da produção e do consumo ou ainda o recenseamento dos indigentes. Guarnecidas com estas estimativas, as cidades organizam o abastecimento de víveres e de perfumes profiláticos, a busca de amas de leite para os órfãos (desde 1586, a cidade de Grenoble cria um rebanho de cabras para alimentá-los). Após 1720, Marselha assume 1300 bebês abandonados.

A peste causa também, para os governantes, uma perda fiscal, em razão da queda drástica do número de contribuintes. Os Estados tentam compensar essa perda com um aumento da pressão fiscal sobre os sobreviventes: aos tempos de peste, seguem os tempos de revoltas antifiscais, cujos exemplos são numerosos nos anos de 1350-1380: os Jacques na França, os Lollards na Inglaterra (com um componente religioso particular), os Tisserands de Gand, os Compi florentinos etc.

Outra consequência é a perturbação do mercado de trabalho. Depois da peste, faltam braços nos ateliês e nos canteiros de obra e os salários tendem a subir. Mestres de ofícios e autoridades civis tentam freiar o encarecimento da mão-de-obra. Eles denunciam os "mendigos válidos", os pobres que poderiam trabalhar com suas mãos, mas preferem recorrer à mendicância21. Os já mencionados Statutes of Labourers promulgados pelo rei da Inglaterra entre 1349 e 1359, o Grande Decreto de João II, o Bom, em 1351, e uma série de textos similares em outras regiões testemunham a vontade de conter o preço da mão-de-obra em benefício do patrão, mobilizando o que Karl Marx chamava de "o exército de reserva de mão-de-obra". Mas essas medidas tiveram efeitos limitados 22. 


\section{Conclusões}

De 1348 a 1720, durante quase quatro séculos, a peste foi uma realidade permanente no coração da história europeia. Ela não esteve presente sempre e em todos os lugares ao mesmo tempo como em 1348, mas entre os ataques súbitos que atingiam cá e lá inesperadamente e os retornos mais ou menos regulares que diminuam seu efeito surpresa, pode-se dizer que cada homem, durante esse longo período, teve uma experiência com a peste ao menos uma vez na vida. E que muitos não sobreviveram a esse encontro.

As consequências da peste foram consideráveis, em primeiro lugar no plano demográfico. Associada a uma mortalidade infantil já muito elevada em tempos normais e a uma esperança de vida reduzida para aqueles que tinham a sorte de passar da infância, ela contribuiu para a estagnação da população entre o início do século XIV e o século XVIII. No século XVII, o reino da França, por exemplo, conta "vinte milhões de franceses"23, sem dúvida um pouco mais do que no final do século XIII. Somente as revoluções médicas e higiênicas do século XIX e XX, cuja vitória sobre a peste será umas das conquistas dentre outras, permitirão forçar os bloqueios demográficos estruturais do período anterior.

Hoje desaparecidas e esquecidas das populações europeias, as devastações passadas da peste deixaram traços materiais, como alguns pedaços do Muro da Peste, que bloqueava a Provença de Oeste a Leste em 1720. Mais antigos, os "vilarejos desertados" também chamam a atenção dos arqueólogos. É o caso do vilarejo medieval de Rougiers, na Provença, que foi local de importantes escavações arqueológicas. Mas essas deserções não têm a peste como única razão: seu grande número na Inglaterra é sobretudo devido à política das "enclosures" da aristocracia, que não hesita em expulsar os camponeses de suas moradias e de seus campos para converter as culturas de víveres em campos destinados à criação especulativa de ovelhas, a fim de abastecer de lã as novas manufaturas têxteis 24 .

Da história da peste faz também parte a evolução dos conceitos de doença ao longo do tempo. Da concepção "aerista", que incriminava uma suposta corrupção do ar e uma perturbação dos elementos, e do medo de um castigo divino, passou-se à idéia de contágio, atribuída, em certos casos, a um organismo vivo e minúsculo, o que abria 
caminho para a revolução de Pasteur e a decisiva descoberta do bacilo da peste por Yersin em 1894. Nessa época, a peste não mais ameaçava a Europa diretamente. Entretempo, a lenta maturação dos conceitos "contagionistas" levou as autoridades a tomar medidas de proteção (quarentena, "fileiras", bloqueio de cidades, isolamento de casas e de pessoas etc), o que, por um lado, permitiu a eliminação da epidemia antes de ser identificada sua causa real e de ter-se desenvolvido um soro para combater o bacilo. Nossa situação diante do Covid-19 é um pouco mais vantajosa porque o vírus foi identificado. Mas ainda não dispomos de vacina para combatê-lo. O que não impede, muito pelo contrário, de rodear-se de meios de prevenção, como as "medidas de contenção", o uso da máscara e a "quatorzena" das pessoas suspeitas.

Outra aproximação entre as duas situações presente e passada diz respeito à difusão internacional da doença e a sua rapidez de propagação, mesmo se essa última é naturalmente bem mais veloz hoje em razão dos meios modernos de comunicação. Deve-se destacar também que a epidemia, já no passado, favoreceu o desenvolvimento da informação sobre a progressão do mal. As cidades italianas mantinham-se mutuamente informadas desde a Idade Média. Os órgãos do Estado moderno em gestação apuravam as cidades atingidas, e viu-se Luís XIV preocupar-se em enviar a Marselha uma delegação de "especialistas" que tinham por missão relatar-lhe a situação. A informação mútua é hoje uma obrigação da comunidade internacional, e os Estados que parecem recusar a regra veem dedos apontados contra si.

Sem dúvida, ainda é muito cedo para dizer quais produções literárias e artísticas o Covid-19 deixará para a posteridade. Sua herança literária será tão brilhante como a da peste? De Boccacio a Camus, passando por Defoe e muitos outros, ela pode triunfar com um belo prêmio literário. Entretanto, a mesma coisa não aconteceu nas artes plásticas, como se a sideração do flagelo tivesse aqui quebrado o impulso criador dos artistas. No passado, atribuiu-se à Peste Negra o nascimento da arte macabra, que expõe complacentemente a decomposição da carne e os horrores da morte. Mas a maioria dos temas macabros da pintura medieval ou da escultura funerária apareceram antes da Peste Negra, ou então se desenvolveram depois dela, nos tempos dos retornos intermitentes da epidemia e de também outros flagelos, a tal ponto que as causas mais gerais, sociais e culturais, devem ser-lhe atribuídas. O Triunfo da Morte e o Encontro dos Três Vivos e dos Três Mortos foram pintados no Campo Santo de Pisa por 


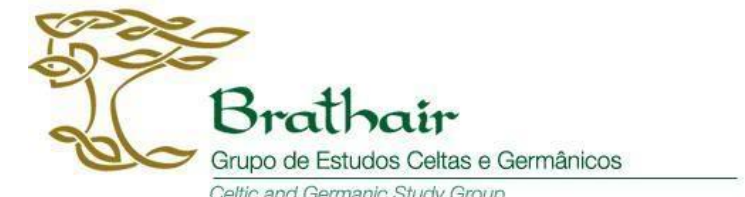

Buonamico Buffalmacco antes de 134825. A fonte literária que inspirou o segundo tema pictórico mencionado é, por sua vez, bem anterior, uma vez que se trata do Dito dos Três Vivos e dos Três Mortos de Baudoin de Condé, aproximadamente entre 1240128026.

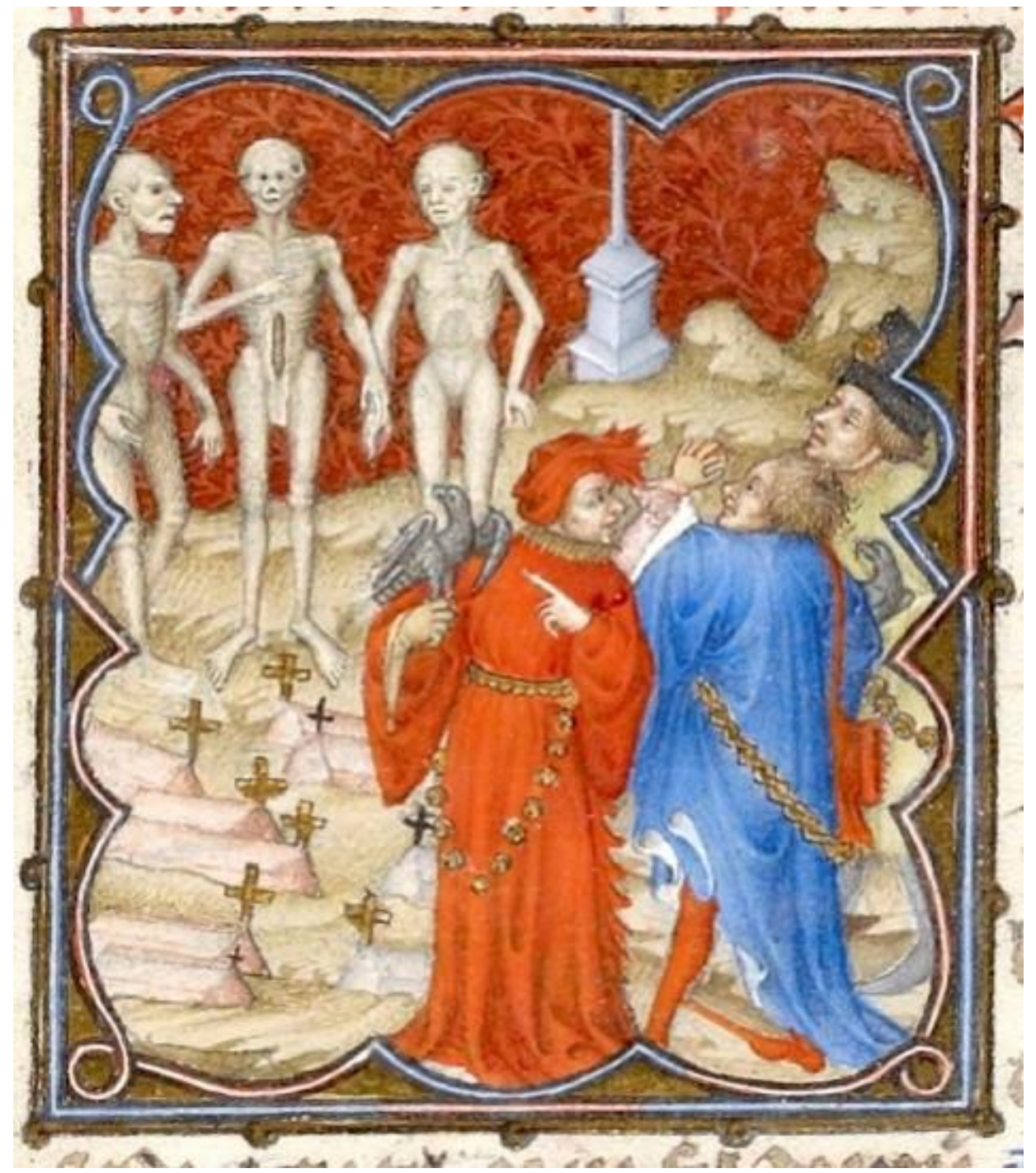

Figura 7: O Dito dos Três Vivos e dos Três Mortos. Miniatura de um Livro das Horas, século XV 
Inversamente, a Dança Macabra não aparece antes do início do século XV: sua primeira representação, em uma das galerias do cemitério parisiense dos Santos Inocentes, data de 1424; ela é conhecida graças às tábuas gravadas par Guyot Marchant em 1485.

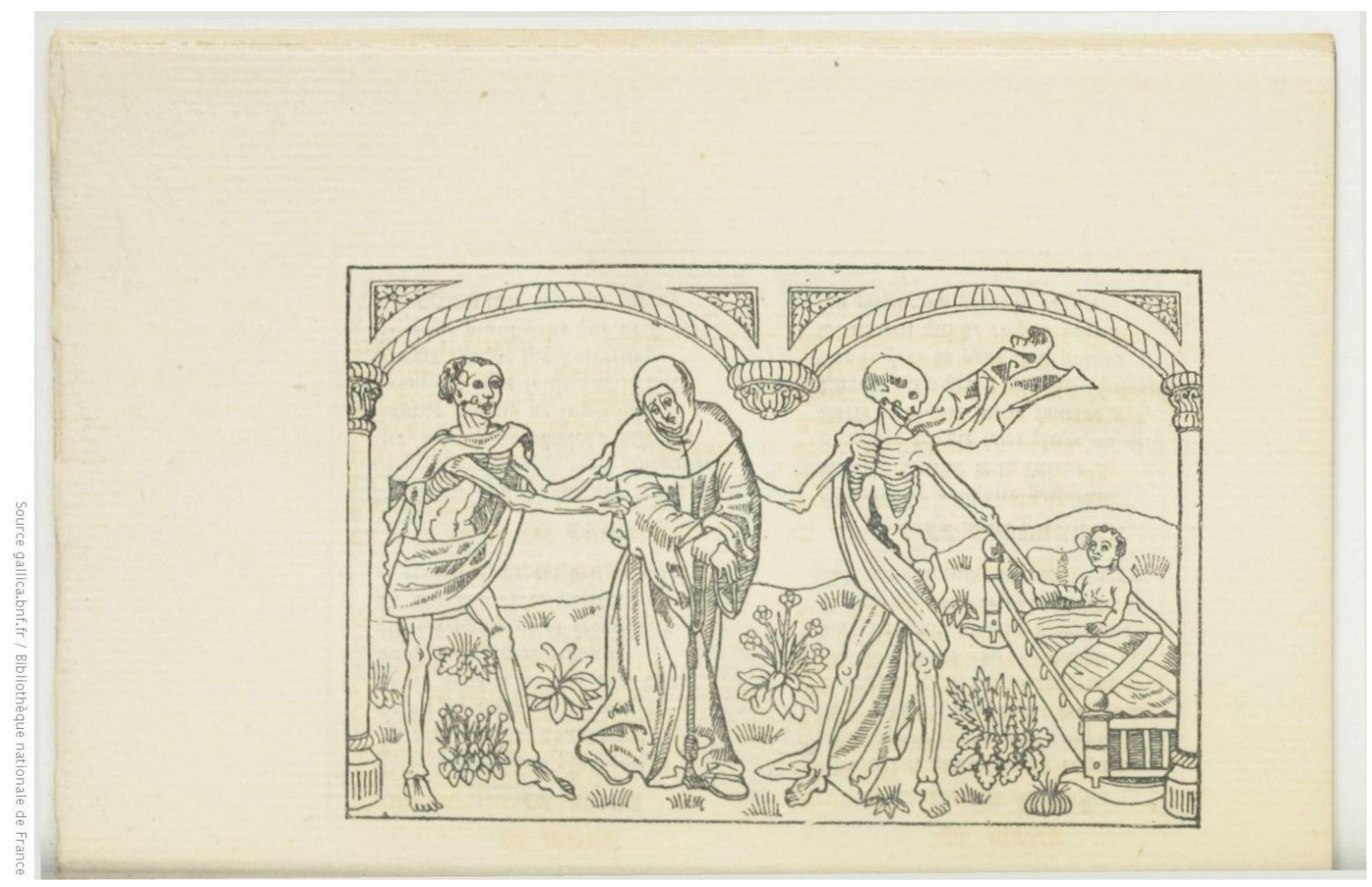

Figura 8: A dança macabra de Guyot Marchant, 1485

Ainda existem, ademais, aproximadamente cinquenta afrescos do século XV representando o mesmo tema em igrejas da França e alhures. No fm da contas, os documentos - ou melhor, os monumentos - que testemunham no calor dos acontecimentos a agressão da peste poderiam ser bastante raros. Mencionei acima os dois quadros pintados da catedral de Puy, que são ex-voto públicos. A eles pode-se comparar a Coluna da Peste (Pestsaüle) erigida em Viena em 1683 em circunstâncias similares; ela foi imitada em outros lugares da Áustria e do sul da Alemanha para recordar a passagem da peste e a salvação milagrosa da população. 


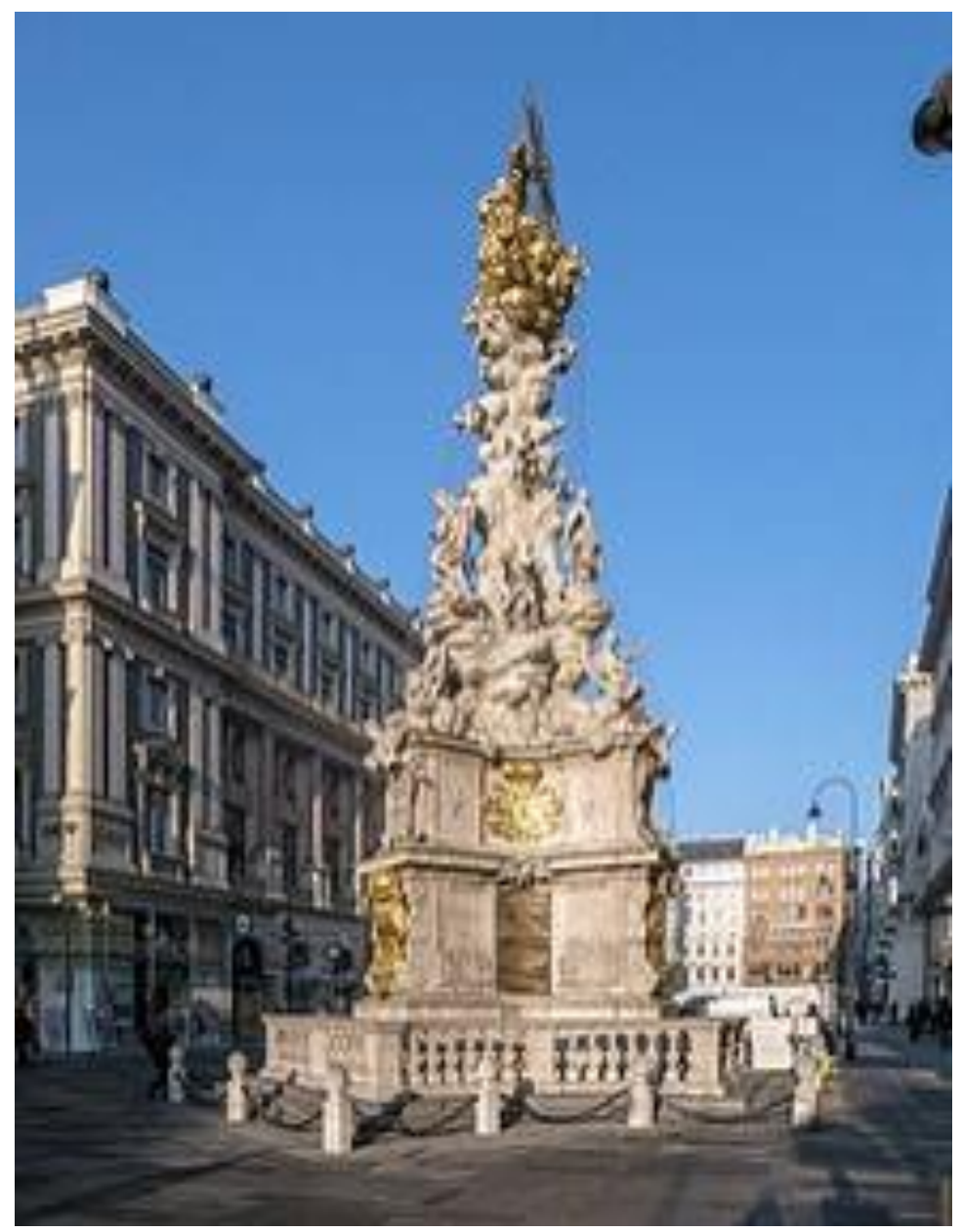

Figura 9: Coluna da peste de Viena, erigida sobre o Graben em 1683

\section{Figuras}

Figura 1: Mapa da disseminação da epidemia de peste em 1348-1352 (Wikipedia).

Figura 2: O "Doutor-Bico" Chicoyneau e a Peste de Marselha em 1720 (Direitos reseravdos).

Figura 3: Vestígios do Muro da Peste na Provença (Wikipedia).

Figura 4: Mapa da disseminação na epidemia na Provença e no Languedoc (J.-N. Biraben, vol. 1, p. 246).

Figura 5: A Virgem da Misericórdia. Estandarte processional pintada por Beneditto Bonfigli, 1464. Perugia, Galleria Nazionale (Direitos reservados). 
Figura 6: Um médico perfura os bubões de uma família vítima da peste. Afresco do século XV, capela São Sebastião de Lanslevillard, Savóia. (Direitos reservados).

Figura 7: O dito dos Três Vivos e dos Três Mortos. Miniatura de um Livro das Horas, século XV (Direitos reservados).

Figura 8: A dança macabra de Guyot Marchant, 1485 (Direitos reservados).

Figura 9: A coluna da peste de Viena, erigida sobre o Graben em 1683 (Wikipedia).

\section{BIBLIOGRAFIA}

Jean-Noël BIRABEN, Les hommes et la peste en France et dans les pays européens et méditerranéens. Tome I: La peste dans l'histoire. Tome II : Les hommes face à la peste, Paris/ La Haye, Mouton, 1975 (Ecole des Hautes Etudes en Sciences Sociales - Centre de Recherches Historiques - Collection Civilisations et Sociétés, 35).

Guy Bois, Crise du féodalisme. Economie rurale et démographie en Normandie orientale du début du XIVe siècle au milieu du XVIe siècle, Paris, Presses de la Fondation nationale des sciences politiques, 1981.

Bruce M. S. CAMPBELL, The Great Transition: Climate, Disease and Society in the Late-Medieval World», Cambridge, Cambridge University Press, 2016.

Albert Camus, La peste à Oran, Paris, Gallimard, 1947.

Hélène Dachez, «Peste, texte et contagion: Le Journal de l'année de la peste (1722) de Daniel Defoe », Dix-huitième siècle, 2015/1, n 47, p. 311 à 324.

Daniel Defoe, Journal de l'Année de la Peste. Trad. française par Francis Ledoux. Préface d'Henri Hubert Mollaret, Paris, Gallimard, 1982. 
Paul Demont, "The Causes of the Athenian Plague and Thucydides",

Thucydides between History and Literature, A. Tsakmakis, M.

Tamiolaki (ed.), Berlin/Boston, De Gruyter, 2013, p. 73-87.

Dit des trois morts et des trois vifs. Éditions, traductions et études des versions médiévales (Essai de translatio collective), sous la direction de Claudio Galderisi, Pierre Nobel et Jean-Jacques Vincensini. Postface de Jean-Claude Schmitt (Bibliothèque de Transmédie. Études et Éditions, 6), Turnhout, Brepols, 2019.

Michael Walters DOLS, The Black Death in the Middle East, Princeton, Princeton University Press, 1977.

Jean-Philippe Genet, «À propos de la « grande transition »: mesure et histoire : Histoire \& mesure, XXXII-2, 2017 (http://journals.openedition.org/histoiremesure/6295).

Jean Giono, Le hussard sur le toit, Paris, Gallimard, 1951. Erik A. Heinrichs, « The Live Chicken Treatment for Buboes: Trying a Plague Cure in Medieval and Early Modern Europe », Bulletin of the History of Medicine, 91, 2, Summer 2017, p. 210-232.

William Chester Jordan, The Great Famine. Northern Europe in the Early Fourteenth Century, Princeton, Princeton University Press, 1996.

Jacques Le Goff et Jean-Noël Biraben, «La peste dans le haut Moyen Âge », Annales E.S.C., XXIV, 1969, p. 1484-1510.

Emmanuel Le Roy Ladurie, Le siècle des Platter, 1499-1628. Tome 1, Le mendiant et le professeur. Tome 2, Le voyage de Thomas Platter, 1595 1599, Paris, Fayard, 2000.

Millard Meiss, Painting in Florence and Siena after the Black Death: the arts, religion, and society in the mid-fourteenth century, Princeton $\underline{\text { University Press, }}$ 1978. Traduction française $: \underline{\text { La peinture à Florence et }}$ à Sienne après la peste noire : les arts, la religion, la société au milieu 
du XIVe siècle. Traduit de l'anglais par Dominique Le Bourg. Préface de Georges Didi-Huberman, Paris, Hazan, 2013.

«Pest », in Lexikon des Mittelalters, VI, Munich, DTV, 2002, col. 19151921

Rudolf von Schlettstadt, Historiae memorabiles. Zur Dominikanerliteratur und Kulturgeschichte des 13. Jahrhunderts, hg. von Erich Kleinschmidt, Köln-Wien, Böhlau, 1974 (Beihefte zum Archiv für Kulturgeschichte, 10).

Anton Serdecny, Du tabac pour le mort : une histoire de la réanimation. Préface de Jean-Claude Schmitt, Ceyzérieu, Champ-Vallon, Coll. Epoques, 2018.

C.-E. A. Winslow and M.L. Duran-Reynald, «Jacme d'Agremont and the First of the Plague Tractates », Bulletin of the History of Medecine, 22, 6 (Novembre-December 1948), p. 747-765.

\section{Notas}

\footnotetext{
${ }^{1}$ Tadução do francês para o português feita pelo Prof. Ms. Thiago de Souza Ribeiro Chaves (PEM-UnB).

2 Diretor do Groupe d'Anthropologie Historique de l'Occident Médiéval (GAHOM), (grupo criado por Jacques Le Goff, em 1978) entre 1992 e 2014, na École des Hautes Études en Sciences Sociales (EHESS). Foi presidente do Conselho Científico do Campus Condorcet.

${ }^{3}$ Este artigo desenvolve o tema de uma conferência pública organizada pelo município de Vialas, no departamento da Lozère, na França, em 13 de agosto de 2020.

${ }^{4}$ N.T.: O termo "quatorzaine", aqui traduzido para "quatorzena", é um neologismo corrente em língua francesa para referir-se à quarentena de quatorze dias imposta nos tempos da pandemia de COVID-19.

${ }^{5}$ Este conceito foi proposto aos historiadores europeus por Jacques LeGoff.

${ }^{6} \mathrm{O}$ melhor estudo de conjunto da história da peste na Europa continua sendo o de Jean-Noël BIRABEN, Les hommes et la peste en France et dans les pays européens et méditerranéens (Os hommes e a peste na França e nos passes europeus e mediterrâneos). Volume I: La peste dans l'histoire (A peste na história). Volume II: Les hommes face à la peste (Os homens diante da peste), Paris, La Haye, Mouton, 1975 (École des Hautes Études en Sciences Sociales - Centre de Recherches Historiques - Collection Civilisations et Sociétés, 35). Faço, neste artigo, diversos empréstimos implícitos a essa obra.

7 William Chester Jordan, The Great Famine. Northern Europe in the Early Fourteenth Century, Princeton, Princeton University Press, 1996.

${ }^{8}$ Bruce M. S. CAmpbell, The Great Transition: Climate, Disease and Society in the Late-Medieval World», Cambridge, Cambridge University Press, 2016. Ver a resenha de Jean-Philippe Genet, « À propos de la «grande transition »: mesure et histoire : Histoire \& mesure, XXXII-2, 2017 (http://journals.openedition.org/histoiremesure/6295), que escreve em particular: "a pandemia foi desencadeada não porque Yersina pastis chegou à Europa, mas porque ela chegou em 1347, em um momento em que as condições climáticas tornaram-se ótimas para sua difusão”.
} 
9 Tucídides, A guerra do Peloponeso, livro II, "A peste de Atenas". Cf. Paul Demont, "The Causes of the Athenian Plague and Thucydides", Thucydides between History and Literature, A. Tsakmakis, M. Tamiolaki (ed.), Berlin/Boston, De Gruyter, 2013, pp. 73-87.

10 Guy Bois, Crise du féodalisme. Economie rurale et démographie en Normandie orientale du début du XIVe siècle au milieu du XVIe siècle, Paris, Presses de la Fondation nationale des sciences politiques, 1981.

11 Inclusive, confinei-me nele durante a pandemia de Covid-19 em 2020.

12 Marie-Lucie Dumas, "Evolution démographique du Moyen Âge au XIXe siècle », in Vialas de la Cévenne au Mont Lozère, sob a direção de M.-L. Dumas. Prefácio de Pauline Pantel e Jean-Claude Schmitt, Vialas, Le Filon des Anciens, 2019, 2 volumes, volume 1, p. 128. A população atual desse vilarejo, depois de ter chegado a 2500 habitantes na metade do século XIX em razão de uma atividade mineradora e industrial que chegou ao fim em 1894, conta atualmente 450 habitantes... como ao fim da Peste Negra!

13 N.T.: O termo francês "corbeau", literalmente traduzido como "corvo", designava, no século XVI, a pessoa que, em tempos de epidemia, era encarregada pelas autoridades de retirar os cadáveres contaminados da cidade, com a finalidade de colocá-los nas fossas.

14 Daniel Defoe, Journal de l'Année de la Peste. Trad. francesa de Francis Ledoux. Prefácio de Henri Hubert Mollaret, Paris, Gallimard, 1982. Ver Hélène Dachez, « Peste, texte et contagion : Le Journal de l'année de la peste (1722) de Daniel Defoe », Dix-huitième siècle, 2015/1, n ${ }^{\circ}$ 7, pp. 311 à 324.

15 Também a epidemia de Covid-19 suscita especulações milenaristas, que relembram as do passado: ver os artigos de jornal de Joël E. Schnapp: https://www.lepoint.fr/debats/covid-19-et-la-tentationeschatologique-20-05-2020-2376334_2.php e https://www.lesinfluences.fr/Covid-19-vous-reprendrezbien-un-peu-d-Apocalypse.html

16 Rudolf von Schlettstadt, Historiae memorabiles. Zur Dominikanerliteratur und Kulturgeschichte des 13. Jahrhunderts, hg. von Erich Kleinschmidt, Köln-Wien, Böhlau, 1974 (Beihefte zum Archiv für Kulturgeschichte, 10).

17 Emmanuel Le Roy Ladurie, Le siècle des Platter, 1499-1628. Volume 1, Le mendiant et le professeur. Volume 2, Le voyage de Thomas Platter, 1595-1599, Paris, Fayard, 2000, vol. II, p. 381.

18 Ibid., p. 349. A fórmula dessas carteiras é sempre a mesma, como esta (Volume II, p. 349: "Nous, consuls de la ville de Nismes certifions estre parti dicelle, ou Dieu graces a bonne santé, monsieur Thomas Platter ce XII aoust 1598 pour aller a Uses. Le present ne servant que pour ung. Le XII aoust 1598. Rozel, consul" [Nós, cônsules da cidade de Nimes, certificamos que o Senhor Thomas Platter partiu desta cidade para ir a Uzès e que ele está, graças a Deus, em boa saúde, neste 12 de agosto de 1598 . O presente certificado é válido somente para uma pessoa. 12 de agosto de 1598, Rozel, cônsul].

19 Ver o romance de Jean Giono, Le hussard sur le toit, Paris, Gallimard, NRF, 1951.

20 Anton Serdecny, Du tabac pour le mort: une histoire de la réanimation. Prefácio de Jean-Claude Schmitt, Ceyzérieu, Champ-Vallon, Coll. Epoques, 2018.

21 Permito-me recomendar Jean-Claude Schmitt, Mort d'une hérésie. L'Eglise et les clercs face aux béguines et aux bégards du Rhin supérieur, Paris / La Haye / New York, Mouton Editeur / Ecole des Hautes Etudes en Sciences Sociales, 1978 (Coll. Civilisations et Sociétés, 56), pp. 135-194.

22 Bronislaw Geremek, Les marginaux aux XIVe et XVe siècles, Paris, Flammarion, 1976.

23 Título de um célebre ensaio de Pierre Goubert, Louis XIV et vingt millions de Français, Paris, Fayard, 1967.

24 Rodney H. Hilton, «Villages désertés et histoire économique: recherches françaises et anglaises », Études rurales, $\mathrm{n}^{\circ} 32,1968$. pp. 104-109.

25 Millard Meiss, Painting in Florence and Siena after the Black Death: the arts, religion, and society in the mid-fourteenth century, Princeton University Press, 1978. Ver a tradução francesa e o esclarecedor prefácio de G. Didi-Huberman : La peinture à Florence et à Sienne après la peste noire : les arts, la religion, la société au milieu du XIVe siècle. Traduit de l'anglais par Dominique Le Bourg. Préface de Georges Didi-Huberman, Paris, Hazan, 2013.

26 Le Dit des trois morts et des trois vifs. Edições, traduções e estudos das versões medievais (Essai de translatio collective), sob a direção de Claudio Galderisi, Pierre Nobel e Jean-Jacques Vincensini. Posfácio de Jean-Claude Schmitt (Bibliothèque de Transmédie. Études et Éditions, 6), Turnhout, Brepols, 2019. 